\section{Recent Trends in Eukaryotic Transcription: Crucial Role of Gene Architecture in Transcriptional Regulation}

\section{Editorial}

The Human Genome Project has identified more than 25,000 genes in our cells. Not all of these genes are expressed at the same time or in every cell of our body. A fundamental question in gene expression is how the coordinated expression of genes is achieved during growth, development and homeostasis. The expression of genetic information is regulated to a great extent at the level of transcription. In eukaryotes, RNA polymerase II is the main transcription enzyme, which transcribes protein coding genes and a number of non-coding RNAs. The transcription by RNA polymerase II is regulated by cis-acting DNA elements and trans-acting accessory protein factors. The enhancer, promoter and terminator are the most important DNA elements required for transcription by RNA polymerase II, while accessory protein factors include gene-specific transcription factors, the general transcription factors and termination factors. The generally accepted view is that the factors occupying the promoter region play a dedicated role in initiation of transcription and those operating at the terminator end are exclusively required for the termination step of transcription. The research in my and other laboratories has challenged this dogma.

Genomewide analysis has revealed that a number of general transcription factors and termination factors crosslink to both the $5^{\prime}$ and the $3^{\prime}$ ends of genes. We demonstrated that TFIIB, TFIIH and the coactivator Mediator complex, which are essential for initiation of transcription, do not merely localize at the $3^{\prime}$ end of genes, but also play a role in termination of transcription [1-3]. Further research in other laboratories revealed that the function of TFIIB as a termination factor is evolutionarily conserved, occurring in yeast, mammalian systems and flies [4,5]. Similarly, the termination complexes have been found occupying both ends of genes in almost every eukaryotic system that has been investigated so far. The termination factors play a critical role in enhancing promoter directionality, which is favoring promoter-initiated transcription to proceed in the sense direction producing mRNA, while suppressing the transcription of non-coding uaRNA in the upstream anti-sense direction [6-9]. The importance of termination factors in conferring promoter directionality is now well established across eukaryotic taxa.

The next question is how the initiation and termination factors are recruited at both the ends of a gene. Research in my laboratory shows that the promoter and terminator regions of a gene are juxtaposed during transcription resulting in the formation of a gene loop $[10,11]$. Such gene loops are formed due to protein-protein interactions of the factors occupying the distal ends of a gene, and have been observed during transcription in yeast, humans, flies and plants [5,12-14]. The physical proximity of the promoter and terminator regions in the

\section{Journal of}

Cytology \& Molecular Biology

\section{Ansari $\mathbf{A}^{*}$}

Department of Biological Sciences, Wayne State University, USA

\section{*Address for Correspondence}

Ansari A, Department of Biological Sciences, Wayne State University, Detroit, MI 48202, USA; E-mail: ansari@biology.biosci.wayne.edu

Submission: 24 June 2019

Accepted: 03 July 2019

Published: 05 July 2019

Copyright: $\odot 2019$ Ansari A. This is an open access article distributed under the Creative Commons Attribution License, which permits unrestricted use, distribution, and reproduction in any medium, provided the original work is properly cited.

gene loop allows the initiation factors to contact the $3^{\prime}$ end of the gene and affect termination, and termination factors to interact with the $5^{\prime}$ end of the gene and affect promoter directionality. Gene loops also enhance transcription by coupling termination to reinitiation [8].

Apart from promoter-terminator gene loops that have been well characterized in yeast, higher eukaryotes exhibit another type of loop, the enhancer-promoter loop, which also plays a critical role in transcriptional regulation [15]. These observations unequivocally demonstrate that apart from DNA sequence elements and accessory protein factors, gene architecture also plays a vital role in transcriptional regulation in eukaryotes.

\section{References}

1. Medler S, Ansari A (2015) Gene looping facilitates TFIIH kinase-mediated termination of transcription. Sci Rep 5: 12586.

2. Mukundan B, Ansari A (2011) Novel role for mediator complex subunit Srb5/ Med18 in termination of transcription. J Biol Chem 286: 37053-37057.

3. Mukundan B, Ansari A (2013) Srb5/Med18-mediated termination of transcription is dependent on gene looping. J Biol Chem 288: 11384-11394.

4. Wang Y, Fairley JA, Roberts SG (2010) Phosphorylation of TFIIB links transcription initiation and termination. Curr Biol 20: 548-553.

5. Henriques T, Ji Z, Tan-Wong SM, Carmo AM, Tian B, et al. (2012) Transcription termination between polo and snap, two closely spaced tandem genes of $D$. melanogaster. Transcription. 3: 198-212.

6. Almada AE, Wu X, Kriz AJ, Burge CB, Sharp PA (2013) Promoter directionality is controlled by U1 snRNP and polyadenylation signals. Nature 499: 360-363.

7. Tan-Wong SM, Zaugg JB, Camblong J, Xu Z, Zhang DW, et al. (2012) Gene loops enhance transcriptional directionality. Science 338: 671-675.

8. Al Husini N, Kudla P, Ansari A (2013) A role for CF1A 3' end processing complex in promoter-associated transcription. PLoS Genet 9: e1003722.

9. Al-Husini N, Sharifi A, Mousavi SA, Chitsaz H, Ansari A (2017) Genomewide analysis of Clp1 function in transcription in budding yeast. Sci Rep 7: 6894

10. Ansari A, Hampsey M (2005) A role for the CPF 3'-end processing machinery in RNAP II-dependent gene looping. Genes Dev 19: 2969-2978.

11. El Kaderi B, Medler S, Raghunayakula S, Ansari A (2009) Gene looping is conferred by activator-dependent interaction of transcription initiation and termination machineries. J Biol Chem 284: 25015-25025. 
Citation: Ansari A. Recent Trends in Eukaryotic Transcription: Crucial Role of Gene Architecture in Transcriptional Regulation. J Cytol Molecul Biol. 2019;4(1): 2

\section{ISSN: $2325-4653$}

12. Perkins KJ, Lusic M, Mitar I, Giacca M, Proudfoot NJ (2008) Transcriptiondependent gene looping of the HIV-1 provirus is dictated by recognition of pre-mRNA processing signals. Mol Cell 29: 56-68.

13. Tan-Wong SM, French JD, Proudfoot NJ, Brown MA (2008) Dynamic interactions between the promoter and terminator regions of the mammalian BRCA1 gene. Proc Natl Acad Sci U S A 105:5160-5165.
14. Crevillen P, Sonmez C, Wu Z, Dean C (2013) A gene loop containing the floral repressor FLC is disrupted in the early phase of vernalization. EMBO J 32: 140-148.

15. Schoenfelder S, Fraser P (2019) Long-range enhancer-promoter contacts in gene expression control. Nat Rev Genet 2019 May 13. 